\title{
TTIP and Legislative-Executive Relations in EU Trade Policy
}

\author{
Dr Davor Jančić
}

\begin{abstract}
This article analyses Transatlantic Trade and Investment Partnership (TTIP) negotiations in order to assess how the move towards tighter economic integration within the EU-US strategic partnership impacts legislativeexecutive relations in EU trade policy. The analysis examines the institutional, substantive and party political dimensions of national parliaments' scrutiny of the Common Commercial Policy. Based on insights into both domestic and EU channels of parliamentary monitoring of TTIP negotiations, the article argues that, although the government remains the central object of democratic control, NPs' involvement in transatlantic trade extends beyond the government's foreign policy to encompass the EU's own transatlantic and trade policies. This is rooted in the legislatures' legal capacity to constrain the executive in the negotiation, conclusion and, where applicable, ratification phases of EU trade agreements. It is submitted that national parliamentary influence takes the shape of politicisation of the legitimacy of the expected policy outcomes of these agreements.
\end{abstract}

\section{Keywords}

TTIP, national parliaments, transatlantic relations, EU trade policy, mixed agreements

\section{Introduction: The Transforming Nature of Transatlantic Affairs}

With increasing economic and regulatory interdependence between the US and the EU (Jančić 2015; Buonanno 2015; Vogel and Swinnen 2011; Pollack and Shaffer 2001), transatlantic relations began transforming from being solely a matter of bilateral foreign policy of each Member State to being also an EU-wide policy. This metamorphosis was acknowledged in the 1990 Transatlantic Declaration and the 1995 New Transatlantic Agenda (NTA), both of which invoke the importance of parliamentary cooperation. Yet since this refers primarily to the US Congress and the European Parliament (EP), it is unclear to what extent national parliaments of the EU Member States (NPs) are a part of transatlantic trade politics.

First, while both Congress and the EP have a say in EU-US international agreements by means of consent (Servent 2014), NPs only have this right if these agreements are concluded as mixed. Second, in June 2015 Congress granted the US President the so-called Trade Promotion Authority (TPA), or 'fast-track procedure', which enables the US executive to conclude international agreements with limited involvement of Congress if certain 'overall' and 'principal' trade negotiating objectives are upheld (Fergusson 2015). ${ }^{1}$ Although the TPA is not legally required for the US executive to conduct external trade policy, once it is enacted it becomes a binding guarantee of ex ante congressional influence. Neither the EP nor NPs have such a strong tool at their disposal before the onset of trade negotiations. Third, the EP and Congress have since 1999 met on a biannual basis within the Transatlantic Legislators' Dialogue (TLD), which has been developing 'ever-broader agendas' to mirror EU-US intergovernmental meetings (Burghardt 2015: 219). No such transatlantic interparliamentary forum exists for NPs, which has led to arguments that they have 'abdicated their control over the making of trade policy' (Meunier 2005: 191).

Negotiations on a Transatlantic Trade and Investment Partnership (TTIP) are an excellent testing ground for studying domestic parliamentary involvement in the EU's Common Commercial Policy (CCP) in the context of 'competitive interdependence' between the EU and the US (Sbragia 2010), whereby they pursue separate but parallel strategies of global trade liberalisation through free

\footnotetext{
${ }^{1}$ Bipartisan Congressional Trade Priorities and Accountability Act of 29 June 2015 (P.L. 114-26, 19 USC 4201).
} 
trade arrangements with partners worldwide (Woolcock 2014). ${ }^{2}$ Transatlantic relations have recently intensified through the conclusion of bilateral agreements, such as the PNR and SWIFT Agreements, regarding which the EP has been able to make its voice heard (Fahey 2014). As transatlantic relations become an important dimension of EU foreign policy, carrying far-reaching legal and politicoeconomic implications for the Member States, they increasingly fall under the NPs' scrutiny of EU affairs (Gstöhl and Hanf 2014: 745).

This article argues that, as a result, domestic parliamentary participation in EU-US relations has begun expanding to encompass not only the government's foreign policy but also the EU's own transatlantic policy. This development is analysed to establish the impact that the burgeoning EU-US partnership has on legislative-executive relations in EU trade policy. TTIP is utilised as a case study due to its political salience, regulatory consequences, and its conduciveness to politicisation and galvanisation of parliamentary interest. It is recognised, however, that precisely these features make TTIP a unique case. For this reason, TTIP is best understood as a generator of robust parliamentary response that may leave a mark on future cases of foreign trade negotiations, rather than as a proof that long-lasting shifts in the equilibrium in legislative-executive relations have already taken place.

The objective of the present inquiry is to examine the institutional channels through which NPs scrutinise TTIP negotiations and to inspect the substantive and party political dimensions of their pronouncements. This is carried out through an empirical illustration, drawing on the examples of the French and British parliaments. The goal is to depict parliamentary instruments used in trade policy rather than to provide a systematic assessment of the actual influence that these may produce. The analysis confirms the centrality of the government as the primary object of political control, while showing that legislatures also reach out to the EU level in search of influence over trade negotiations-a practice of proactive engagement that has characterised Congress for decades (Carter and Scott 2009).

In the following sections, the article presents an overview of the role of parliaments in international political economy (2) and briefly surveys the most contentious elements of TTIP (3) in order to elucidate the importance of parliamentary participation. This is followed by a legal analysis of the avenues of influence available to NPs in the CCP in both negotiation, conclusion and, where relevant, ratification phases of trade agreements (4). The analysis then inspects how these avenues are used in political praxis by delving into the domestic (5) and EU level (6) channels of NPs' involvement in TTIP negotiations. Their response warrants the conclusion (7) that, despite the lack of firm veto guarantees, NPs are active players in EU trade policy and important stakeholders in trade negotiations (Streinz 2015: 278). TTIP showcases a high level of national parliamentary responsiveness at both domestic and EU levels and this vindicates the thesis that legislatures are increasingly pressuring the executives to improve their standing in trade policy making (Capling and Low 2010: 7).

\section{International Political Economy and the Role of Parliaments}

Political economy is an area where parliaments are presumed to have more leeway to influence the government than in the security and defence segments of external relations. Trade matters are believed to have a more tangible effect on wealth distribution, which is of direct concern to the taxpayer. In consequence, parliamentarians have a greater electoral incentive to scrutinise trade affairs and they indeed utilise numerous instruments-such as resolutions, debates, and hearings-to represent the interests of their constituencies (Raunio 2014: 549-550; Hiscox 2002; Milner and Tingley 2011: 45). This constituency-oriented approach is traceable in both the US and the EU, with Congress, the EP and NPs all attempting to satisfy both export-dependent and import-competing demands (Bièvre

\footnotetext{
${ }^{2}$ European Commission, 'Trade for All-Towards a More Responsible Trade and Investment Policy', October 2015.
} 
and Dür 2005: 1274). The key power that parliaments typically have in this respect is the right to approve international trade agreements. ${ }^{3}$

With the focus of multilateral trade shifting to 'behind-the-border' issues, such as regulatory approximation and investment, parliamentary bodies have taken a greater interest in trade policy and assumed a more proactive approach to its shaping (Young and Peterson 2006: 795). However, an EP study of the adaptation of 15 countries to the globalisation of trade finds that NPs tend to cling to traditional, state-oriented methods of scrutinising trade policy. ${ }^{4}$ This study attested that the firmer the unity between parliamentary majority and the government, the weaker and less independent the policing of trade affairs will be. Conversely, in times of divided government or cohabitation, parliament is likely to have a stronger grip over the executive's trade policy (Lohmann and O'Halloran 1994). The influence of scrutiny, nevertheless, greatly depends on the formal parliamentary powers in trade policy making. ${ }^{5}$ Congress is a salient example of a legislature that is successful in minimising agency loss and reducing conflict with the executive (Conceição-Heldt 2013). This is owed to the TPA, which combines detailed rule-based ex ante negotiation mandates with strong oversight mechanisms, thereby ensuring a steady flow of information between the US Trade Representative and Congress, which is pivotal to effective accountability.

The EU's rise as a global power, not only in trade but also through trade (Meunier and Nicolaïdis 2006: 907), adds another layer of complexity to the problem of democratic participation. Not only do Member States have distinct trade preferences, but the EU conducts its own commercial policy (Elgström and Larsén 2010). This means that NPs are faced with two channels through which foreign trade is regulated: the government's and the EU's. The principal-agent chain of delegation, therefore, does not stop when authority is passed from voters to parliament and from parliament to government, but carries on when governments gathered in the Council delegate power to the Commission (Dür and Elsig 2011: 332). This enmeshing of international, EU and domestic policymaking processes in the field of trade emphasises its 'intermestic' character and the need for parliamentary involvement (Baldwin 2006: 929).

\section{TTIP's Future Legacy}

If concluded, TTIP will become the world's largest free trade agreement to date. According to congressional estimates, the EU and the US account for close to a half of global GDP, some $30 \%$ of global exports, and have investments in each other's economies in excess of $\$ 3.7$ trillion. While mutual market access is already rather liberalised, TTIP aims to eliminate or lower the remaining obstacles to trade and investment (Lester and Barbee 2013), improve regulatory cooperation, and set global trade rules (Gardner 2015). All of this is expected to boost economic growth and jobs creation.

However, TTIP raises a number of politically sensitive issues. One of the most salient ones concerns dispute settlement. The initially foreseen investor-state dispute settlement (ISDS) mechanism (Bronckers 2013) was widely criticised for favouring the investor's financial interests over the ability of the host state freely to pursue its public policy. This is why ISDS was replaced by a proposal for an Investment Court System. Further sticking points include the scope of the agreement and ways to approximate regulatory standards in areas such as vehicles, chemicals, cosmetics, engineering equipment, medical devices, pesticides, pharmaceuticals, textiles, and information and communication technologies. Regulating genetically modified organisms (GMOs) and safeguarding intellectual property rights (e.g. geographical indications) are equally salient. Institutionally, opposition to the establishment of a Regulatory Cooperation Body caused it to be demoted merely to

\footnotetext{
${ }^{3}$ Yet this is not the case with countries with a strictly 'dualist' approach to international law, such as Canada or the UK, where parliaments have an ex post role in implementing agreements.

${ }^{4}$ EP Study 'The Role of Parliaments in Scrutinising and Influencing Trade Policy' (Andreas Maurer et al.), December $2005,14$.

${ }^{5}$ Ibid, 16.
} 
an 'effective coordinating structure' between regulators. TTIP also raises horizontal issues, such as the exchange and protection of personal data, environment protection and sustainable development.

These issues are amenable to parliamentary debate, because they necessitate the making of political choices (Baldwin 2006: 941), which are contingent on the preferences and interests of the negotiating parties and on the values that underpin their existing policies. Since these differ in the EU and the US, the questions of democracy and citizen participation (Petersmann 2015) as well as those of transparency and accountability emerge as important ingredients of TTIP's legitimacy. While both the EP and Congress are actively engaged in appraising TTIP negotiations (Jančić 2016), NPs also scrutinise them through various channels.

\section{National Parliaments and EU Common Commercial Policy}

Parliaments draw their authority to impose ex ante conditions in trade negotiations from their formal powers in: (a) the negotiation and conclusion phases (EU level); and (b) where required, an additional ratification phase (national level), which according to an EU 'constitutional convention' intervenes between the negotiation and conclusion phases at the EU level (Schütze 2014: 204).

\subsection{National Veto as Source of Influence in the Negotiation and Conclusion Phases}

Following the Lisbon Treaty, the CCP is based on uniform principles relating inter alia to the conclusion of agreements on tariffs, trade in goods and services, the commercial aspects of intellectual property, foreign direct investment, and measures aimed at liberalising as well as protecting trade. ${ }^{6}$

Regarding TTIP, the general procedure for the conclusion of EU international agreements applies. ${ }^{7}$ The Council acts by a qualified majority to approve the Commission's negotiating mandate and, after obtaining consent from the EP, to authorise the Commission to conclude the agreement. While the EP therefore has an essentially post facto say (Krajewski 2013), it is the Council voting rules that determine NPs' influence in the negotiation phase. Namely, unanimity in the Council is required concerning: (a) agreements on trade in services, the commercial aspects of intellectual property, and foreign direct investment, where they address a matter for which unanimity is required for the adoption of EU rules; (b) agreements on trade in cultural and audiovisual services, where they risk prejudicing cultural and linguistic diversity in the EU; and (c) agreements on trade in social, education and health services, where they risk seriously disturbing the national organisation of such services and the Member States' responsibility to deliver them. ${ }^{8}$ Many areas to be covered by TTIP regulate matters where a national veto would be appropriate.

These exceptions to qualified majority voting in the Council provide each individual government with the veto power and give them a 'decisive role' (Dimopoulos 2010: 159). This enables NPs to influence their state's representative in the Council and increase their otherwise 'reduced' input in EU external trade (Krajewski 2005: 126). The formal exclusion of NPs is aggravated by the technocratic nature of EU trade policy making, which makes it difficult for nonexpert legislators to conduct timely monitoring of fast-paced and highly technical trade negotiations that are usually far removed from domestic politics (Woolcock 2012: 52). Remedying this is important for the EU's input legitimacy. The absence of parliamentary scrutiny of commercial policy in contemporary societies is indeed untenable if there is to be even a semblance of democratic decision making' (2011: 458). There is, hence, a need to combine EU and national parliamentary resources of democratic legitimacy (Telò 2015: 37).

\subsection{Mixity as Source of Influence in the Ratification Phase}

\footnotetext{
${ }^{6}$ Article 207(1) TFEU.

${ }^{7}$ Article 218 TFEU.

${ }^{8}$ Article 207(4) TFEU.
} 
The EU Treaties prohibit using the CCP to rearrange the delimitation of competences between the Union and the Member States. ${ }^{9}$ Because this relates to the EU's vires and may touch on national sovereignty, this prohibition represents another potential avenue of NPs' influence in trade negotiations.

To wit, even where conditions for unanimity voting in the Council are met, this does not automatically render those agreements mixed (Bungenberg 2010: 152), and only if an agreement is treated as mixed does it have to approved in accordance with national constitutional rules. Except where a referendum is organised or where constitutional rules do not demand prior parliamentary intervention (e.g. the UK), a mixed agreement will have to be approved by the NP before the EU may conclude it. In legal terms, parliaments are thereby afforded an independent, albeit ex post, right of influence. In political terms, however, the pressure for parliaments not to frustrate often delicately reached deals, strong party discipline, and the very functioning of parliamentary democracy-whereby a government must command a majority in parliament to stay in power-significantly qualify the actual effect that the right of parliamentary approval can produce.

Mixity typically arises when a trade agreement, whether or not it requires unanimity in the Council, regulates not only matters that fall within the EU's exclusive competence within the CCP but also those that fall under the competence shared between the Union and the Member States or under the latter's exclusive competence. This happens frequently because international agreements- $a$ fortiori comprehensive trade deals-address policy areas beyond commerce. Since such agreements engage the competence of the Member States, the latter need to act both within the Council (EU competence) and outside of it as sovereign states (national competence).

Yet even where an agreement regulates non-exclusive EU matters, there is no certainty that the agreement will be mixed, because these matters might be adjudged as 'ancillary' as opposed to 'essential' elements of the agreement. ${ }^{10}$ Whether an agreement is concluded as mixed ultimately depends on bargaining between the Commission and the Member States. Although mixed agreements ensure 'additional reinforced unanimity' (Maresceau 2010: 12), they remain alien to the wording of the Lisbon Treaty (Dashwood 2010: 351). There is hence no formal guarantee of NPs' imprint on EU trade agreements.

TTIP could be categorised as a 'mixed trade and cooperation agreement with political dialogue' (Maresceau 2010: 24). TTIP's mixity is vindicated both by its broad scope with policy impacts beyond trade and by plans to institutionalise long-term regulatory cooperation with important repercussions for national sovereignty (Alemanno 2015: 627; Meuwese 2015). The proposed 'coordinating structure' for regulatory cooperation is envisaged as aiding upstream consultation and exchange of information on legislative and regulatory planning between US federal agencies and the European Commission in order to avoid the adoption of divergent or conflicting rules through a system of early warnings (Jančić 2015: 354). This allows TTIP to be adapted to the changing global regulatory landscape without reopening the negotiations. This self-moulding character of TTIP, which makes it a 'living agreement', ${ }^{11}$ also speaks in favour of mixity and therefore of NPs as political 'arbiters' beside the EP.

These considerations reveal that there are several legal avenues for NPs' influence over EU trade policy. Yet numerous hurdles need to be overcome before the 'legal capital' can translate into 'political gain'. The following two sections focus on NPs' scrutiny of TTIP negotiations in order to investigate whether legislatures' right of consent to mixed EU agreements is utilised as a bargaining chip in their relations with the executive (Mansfield and Milner 2012: 17).

\footnotetext{
${ }^{9}$ Article 207(5) TFEU.

${ }^{10}$ Case C-268/94, Portugal v. Council [1996], ECR I-6177.

${ }^{11}$ Karel de Gucht, 'Transatlantic Trade and Investment Partnership (TTIP)-Solving the Regulatory Puzzle', 10.10.2013, press release SPEECH/13/801, 6 .
} 


\section{Domestic Channels of National Parliamentary Involvement in TTIP Negotiations}

In response to the above limitations, many NPs adopted a proactive approach seeking to shape their executive's trade policy. This is illustrated below with the institutional arrangements and empirical examples from the British and French parliaments' scrutiny of TTIP negotiations. These two cases are analysed both through their substantive pronouncements as unitary institutions and through the lens of party politics. The UK and France have been selected to showcase how differences in the system of government (parliamentary in the UK and semi-presidential in France) are reflected in the practices of parliamentary scrutiny and in the level of legislative-executive cohesion in trade policy.

\subsection{Institutional Arrangements for Scrutinising EU Trade Policy}

The developments in EU trade policy have provoked a remarkable reaction in NPs. The survey conducted to inform the May-June 2015 COSAC meeting reveals several trends. ${ }^{12}$

First, most NPs use ordinary scrutiny instruments to appraise EU trade policy, including meetings and hearings with government representatives. Ex ante mandates are issued in the Baltic (Estonian Riigikogu, Lithuanian Seimas, Latvian Saeima), Nordic (Danish Folketing, Finnish Eduskunta, Swedish Riksdag) and some Central and Eastern European Member States (Slovak Národná Rada, Romanian Camera Deputatilor). Contrarily, only six out of the 34 responding parliamentary chambers did not have any role in defining national priorities for EU trade and investment negotiations. Besides the Cypriot Vouli and the Swedish Riksdag, these were the upper chambers-the UK House of Lords and the Polish, French and Romanian Senates-which is consonant with their reduced role in foreign policy. The latter nevertheless perform scrutiny through other means.

Second, the CCP is typically debated in committees on European, economic and foreign affairs. Specifically, TTIP negotiations have been discussed by no less than 32 parliamentary chambers, while others have made plans to do so. However, a large majority of parliaments did not organise public consultations or prepare their own impact assessments of EU trade and investment policy.

Third, the same majority of 32 chambers have received information on TTIP from the government either upon request or through usual procedures for information exchange. COSAC accordingly called for an ongoing dialogue and information flow to be maintained between NPs and the Commission, the EP and national governments. ${ }^{13}$

\subsection{Substantive Scrutiny of TTIP}

Examining the contents of NPs' scrutiny of TTIP negotiations provides insight into the depth, manner and strategies of parliamentary engagement. As the British and French examples show, these aspects can be performed in various ways and tailored to accomplishing different goals.

In the UK, both Houses of Parliament have thoroughly scrutinised TTIP. In the House of Commons, the Business, Innovation and Skills Committee published a report on TTIP, focusing on the impact on the National Health Service (NHS) and the inclusion of ISDS. ${ }^{14}$ They received assurances from both the Commission and the Government that ISDS would not harm the NHS. ${ }^{15}$ The Commons Environmental Audit Committee also assessed TTIP, arguing against the erosion of the EU's precautionary principle, ${ }^{16}$ and estimating that there was sufficient scope to address

${ }^{12}$ COSAC, $23^{\text {rd }}$ Bi-annual Report (LIII meeting, 31.5.-2.6.2015, Riga), 42-47 and 52.

${ }^{13}$ COSAC, Contribution (LIII meeting, 31.5.-2.6.2015, Riga), paras 3.4, 3.5, 3.9, 3.10, and 3.11.

${ }^{14} \mathrm{HC} 804,11^{\text {th }}$ Report of 2014-15, 25.3.2015, para. 4.

${ }^{15} \mathrm{Ibid}$, paras $47-48$.

${ }^{16}$ HC 857, 9 $9^{\text {th }}$ Report of 2014-15, 10.3.2015, para. 16. 
environmental risks. ${ }^{17}$ For its part, the European Scrutiny Committee held evidence sessions with the competent ministers of state (David Lidington for Europe and Lord Maude for Trade and Investment), where questions were raised about the transparency of TTIP negotiations and the likely consequences on Britain's economy and public services. ${ }^{18}$ This Committee requested that the Government secure a commitment from the Commission to allow MPs and peers equivalent access to information as MEPs. ${ }^{19}$ The Foreign Affairs Committee, furthermore, found that TTIP would have a 'significant positive strategic impact for the UK' ${ }^{20}$ The Health Committee was also active in scrutinising TTIP and an All-Party Parliamentary Group on TTIP was established to promote an informed debate. ${ }^{21}$

The House of Lords EU Committee produced an in-depth report on TTIP, offering a sectoral analysis based on evidence from the Government, the former EU Trade Commissioner Karel De Gucht, and the Chief EU TTIP Negotiator Ignacio Garcia Bercero. Their Lordships concluded that TTIP would bring 'substantial economic benefits to both parties' and viewed institutionalised regulatory cooperation as a revitalising factor in the EU-US partnership and a key sign that TTIP is both an economic and a political instrument. ${ }^{22}$

The French Parliament responded to TTIP negotiations by adopting a series of European resolutions. The Assemblée nationale reacted early demanding the exclusion of cultural and audiovisual services from TTIP, failing which the Government was requested to use its veto in the Council. ${ }^{23}$ These sectors were subsequently removed. Three days later, this chamber passed a resolution on the Commission's negotiating mandate, imposing 'red lines' on intellectual property, data protection, health and environmental standards, public services, and the exclusion of ISDS. MPs also called for a timely provision of information in light of their right to approve the agreement. Moreover, they requested for NPs be included in the work of the TLD. ${ }^{24}$ The bulk of these demands were reiterated in resolutions on a draft TTIP agreement ${ }^{25}$ and on the Commission's Work Programme. $^{26}$

The Sénat was also vigilant. Much like the House of Lords, the senators, in their resolution on the opening of negotiations, held that TTIP would substantially contribute to economic growth and jobs creation. Yet they also mentioned the possibility of vetoing the agreement. ${ }^{27}$ In a further resolution on ISDS, they called for a corresponding revision of the TTIP and CETA agreements, while insisting on enhanced transparency, better access to documents, and closer scrutiny over the Council. ${ }^{28}$ Finally, a resolution was passed requiring certain agricultural safeguards (particularly the protection of geographical indications) and greater involvement of Parliament, the EP and citizens so as to increase transparency and democratic participation. ${ }^{29}$ The senators additionally called upon the Government to request from the Commission a comprehensive sector-by-sector study of TTIP's impact on agriculture.

\subsection{Party Politics of TTIP Negotiations}

\footnotetext{
${ }^{17}$ Ibid, para. 38.

${ }^{18}$ See oral evidence sessions in: HC 292 of 11.6.2014, HC 1084 of 26.2.2015, and HC 553 of 21.10.2015.

${ }^{19} \mathrm{HC} 918,38^{\text {th }}$ Report of 2014-15, 25.3.2015, para. 61.

${ }^{20} \mathrm{HC} 695,8^{\text {th }}$ Report of 2013-14, 3.4.2014, para 53.

${ }^{21}$ See: http://tradeinvest.babinc.org/ttip/all-party-parliamentary-group.

${ }^{22}$ HL Paper 179, $14^{\text {th }}$ Report of 2013-14, 13.5.2014, paras 33 and 74.

${ }^{23}$ AN Résolution européenne 155, 12.6.2013, point 5.

${ }^{24}$ AN Résolution européenne 156, 15.6.2013, points 22 and 23.

${ }^{25}$ AN Résolution européenne 339, 22.5.2014.

${ }^{26}$ AN Résolution européenne 487, 19.3.2015, point 16.

${ }^{27}$ Sénat, Résolution européenne 164, 9.6.2013.

${ }^{28}$ Sénat, Résolution européenne 57, 3.2.2015.

${ }^{29}$ Sénat, Résolution européenne 83, 4.2.2016.
} 
As discussed in the introductory article of this collection, trade policy might cause greater party political cleavages than purely foreign or security policy. It is thus instructive to inspect the positions of different political parties towards TTIP and assess how their attitudes affect the bargaining ability of parliament towards the executive in two different systems of government-those of Britain and France.

The 2015 electoral manifestos of the major British political parties reveal significant convergence in their overall support for TTIP. ${ }^{30}$ While the Tories highlight billion-pound benefits of TTIP, Labour pledge to hold the Commission accountable for TTIP's impact on public services, especially the NHS, and the inclusion of ISDS. The Scottish National Party also promises to seek exemptions for the public sector, particularly the NHS. Similarly, Liberal Democrats support TTIP for the financial advantages for UK economy as long as the agreement upholds EU standards of consumer, employee and environmental protection. The two parties strongly opposing TTIP are UKIP and the Greens. They object on grounds of perceived adverse consequences for national sovereignty through ISDS, encroachment on the NHS, and the opaqueness of negotiations.

When it comes to the role of Parliament in trade policy, House of Commons plenary debates confirm a higher level of activism among backbenchers and Labour opposition MPs than the frontbench Conservative members. In a debate initiated by the All-Party TTIP Group, ${ }^{31}$ a number of Labour MPs voiced their concerns: that TTIP could thwart Parliament's decision-making powers; ${ }^{32}$ that NPs would be presented with a fait accompli; ${ }^{33}$ and that there was thus a need to strengthen mechanisms for consulting NPs so that they have an 'opportunity to comment on or shape the context of the discussions'. ${ }^{34}$ Similarly, a Labour/Co-op MP, Geraint Davies, initiated a debate on ISDS, which ended with a resolution that TTIP and any ISDS provisions 'should be subject to scrutiny in the European Parliament and the UK Parliament'. ${ }^{35}$ This motion was welcomed by several Conservative MPs. ${ }^{36}$

In harmony with the nature of the chamber, the House of Lords plenary debate on its indepth report on TTIP focused on expert-driven, non-partisan appraisal of the issues at stake in the negotiations rather than causing cleavages along party political lines. ${ }^{37}$

Unlike the UK, France is traditionally more sceptical towards globalisation and trade liberalisation. Whereas the British political debate mostly centres on shielding the NHS, that in France mainly revolves around ISDS. Other contested matters include the erosion of regulatory standards, the autonomy of public services, and the protection of intellectual property rights in agriculture. The 2014 EP election campaign was instrumental to mobilising party political positioning on TTIP, which ultimately resulted in cross-party opposition to TTIP (Fabry 2015: 3). Particularly vocal were the smaller left-wing opposition parties such as the Left Front (Front de Gauche), the Communists (Parti Communiste), the Greens (Europe Écologie-Les Verts) and the rightwing National Front (Front National). The centrist parties, the Democratic Movement (MoDem) and especially the Union of Democrats and Independents (UDI), are also rather critical of TTIP. The two largest parties, the Republicans (successor of UMP as of May 2015) and Socialists, are only

\footnotetext{
${ }^{30}$ EurActiv, 'British Candidates Embrace TTIP as “Biggest Prize” for UK in Europe', 23.4.2015, http://eurac.tv/n6M.

${ }^{31}$ HC Deb 25 Feb 2014, Commons Hansard, cols. 186-234.

${ }^{32}$ Kate Clark, col. 221.

${ }^{33}$ Jeremy Corbyn, col. 232.

${ }^{34}$ William Bain, col. 230.

${ }^{35}$ HC Deb 15 Jan 2015, col. 1118

${ }^{36}$ HC Deb 15 Jan 2015. See reactions by Anne Main (col. 1076), Robin Walker (col. 1081), and Robert Walter (col. 1085).

${ }^{37}$ HL Deb 17 Jun 2014, Lords Hansard, cols 727-763.
} 
moderately supportive of this agreement (Fabry 2015: 8). The latter party, however, has evinced concrete and wide-ranging reservations regarding TTIP. ${ }^{38}$

Regarding parliamentary involvement in trade policy, all four resolutions passed by the Assemblee nationale emphasise this aspect of TTIP negotiations and they were all moved by a combination of Communist, Green and Socialist MPs. In the Sénat, two resolutions were initiated by the Communist group and one by the Greens.

Therefore, in both Britain and France, protectionist impulses are more detectable among the left-leaning parties. They were also the ones to demand a greater implication of Parliament in external trade.

\subsection{Assessment of National Parliamentary Involvement in TTIP Negotiations}

The UK and French cases unearth different parliamentary approaches to scrutinising TTIP and EU free trade agreements in general. These are a corollary of their political culture, tradition of scrutiny of EU affairs, and system of government.

While the British parliamentary scrutiny was predominantly 'evidence-oriented', the French was more 'influence-oriented'. Westminster's approach aimed primarily at the domestic mainstreaming of the TTIP debate (Gattermann et al. 2013). This was facilitated by the largely positive attitude of the Conservatives and Labour towards TTIP, and by the absence of the main critics, UKIP and the Greens, from both government and Parliament. ${ }^{39}$ This bipartisan consent regarding the political desirability of TTIP reduced inter-party conflict, thus creating a less confrontational Westminster-Whitehall relationship than the UK's parliamentary system would suggest.

The French Parliament's approach was more inspired by the wish to shape EU decisionmaking outcomes, which reflects the semi-presidentialist principle of institutional autonomy of the legislature from the executive. Parliament's assertiveness on TTIP echoes the fact that the legislature and the President of the Republic, who is a key figure in foreign policy, have separate electoral mandates. However, some parliamentary demands, such as those on the exclusion of cultural and audiovisual services from TTIP, were made not to oppose but to buttress the Government's action. ${ }^{40}$ This was facilitated by the lack of cohabitation between the Presidency and the Government-cumparliamentary majority: both Prime Ministers Jean-Marc Ayrault and Manuel Valls, during whose terms of office TTIP has been negotiated, are members of the Socialist Party, like President François Hollande.

The analysis thus confirms the scholarly assertions that constitutional specificities are often moderated by political realities. In trade policy, legislative participation and oversight were triggered less by the lack of trust in the executive and by the mechanics of the system of government, than by the ideological preferences of the political parties. Indeed, both the UK and France exhibit similarities in party political attitudes towards TTIP. The left-right cleavages, albeit not clear-cut, are discernible regardless of the system of government. The left of the political spectrum and the opposition parties have been the most insistent on securing adequate safeguards and on guaranteeing a stronger role of parliaments in trade negotiations. The leftist parties were hence the engines of the politicisation of TTIP, which coheres with their disenchantment with trade liberalisation. Correspondingly, the rightwing parties are more willing to grant discretion to the executive to conduct foreign trade (Milner and Judkins 2004). TTIP negotiations therefore did not fundamentally alter the nature of domestic policy making on international trade.

38 'Les conditions du groupe S\&D sur le TTIP', 19.5.2014, www.parti-socialiste.fr/articles/les-conditions-du-groupe-sd-surle-ttip.

39 The Greens had one MP in Parliament after the 2010 general election.

${ }^{40}$ See interventions by Pierre Lequiller and Joaquim Pueyo in: AN Commission des affaires européennes, Compte rendu 63,

28.5.2013, www.assemblee-nationale.fr/14/europe/c-rendus/c0063.asp\#P23_1089. 


\section{EU Channels of National Parliamentary Involvement in TTIP Negotiations}

Beyond domestic channels, NPs have also exerted pressure on the Commission and made their positions known to EU TTIP negotiators. This shows that legislative-executive relations are not the only channel of parliamentary influence on the CCP, but that NPs also bypass governments and engage in advocacy directly at the EU level. This develops through the Barroso Initiative and interparliamentary cooperation.

\subsection{The Barroso Initiative}

The political dialogue between the Commission and NPs, known as the Barroso Initiative, was one of the channels of NPs' pronouncement on TTIP. This has proven advantageous, because the early warning mechanism does not apply in this field, because negotiations on international agreements are not conducted on the basis of draft EU legislation. A number of parliaments have submitted their views. ${ }^{41}$

The Joint Committee for EU Affairs of the Irish Oireachtas sent a contribution supporting TTIP, while underlining the need for better impact assessments and greater transparency. They called for a more frequent dialogue with the Commission, for closer interparliamentary cooperation, and, like the French Parliament, for NPs' inclusion in the work of the TLD. The Committee also underlined that NPs' role in ratifying mixed agreements needs to be respected. The Commission replied explaining the expected benefits of TTIP, but failed directly to address the modalities of an enhanced involvement of NPs in transatlantic relations.

The German Bundesrat submitted its resolution on the Commission's public consultation on ISDS, assessing it as 'superfluous and very risky' and warning that TTIP can only be concluded as a mixed agreement. ${ }^{42}$ The Commission responded with additional clarifications reassuring the Bundesrat that its concerns had been taken 'very seriously'. ${ }^{43}$

The Austrian Parliament sent its views on the TTIP negotiating mandate. The Nationalrat argued in favour of increased transparency and openness as a prerequisite for the public acceptance of the agreement. The Bundesrat also emphasised the need to shield environmental and social standards, while criticising ISDS. Only the Nationalrat received a reply and a very brief one at that.

Other parliaments also transmitted their opinions. The European Affairs Committee of the Hungarian National Assembly issued an opinion on the Commission's 2015 Work Programme, insisting on greater transparency, mixity, and the maintenance of GMO-free agriculture. Finally, the French and British parliaments sent some of their reports and resolutions to the Commission too.

Furthermore, Commission representatives visited some NPs to discuss TTIP. Notable examples are joint meetings of the French Assemblée nationale and the Sénat with Commissioners Malmström ${ }^{44}$ and Timmermans. ${ }^{45}$ During the latter session, Timmermans expressed awareness of the misgivings of the French parliamentarians and diplomatically stated: 'I believe that we can have an agreement that suits you, but this is not guaranteed'. This remark affirms that direct impact of NPs' on EU trade negotiations is uncertain.

\subsection{Interparliamentary Cooperation}

When it comes to mixed agreements, there is a strong case for interparliamentary cooperation because both the EP and NPs are invited to approve them (Passos 2010: 291). Trying to influence TTIP

\footnotetext{
${ }^{41}$ Based on Commission data: http://ec.europa.eu/dgs/secretariat_general/relations/relations_other/npo/index_en.htm.

${ }^{42}$ Bundesrat, Resolution of 11.7.2014, doc. no. 295/14, points 9 and 12.

${ }^{43}$ Letter of 20.3.2015, C(2015) 1665.

${ }^{44}$ AN, Compte rendu 202, 15.4.2015, www.assemblee-nationale.fr/14/europe/c-rendus/c0202.asp\#P5_289.

45 Sénat, Compte rendu, 17.2.2015, www.senat.fr/compte-rendu-commissions/20150216/europ.html\#toc2.
} 
negotiations, NPs have exploited EU avenues of interparliamentary cooperation through both spontaneous concerted action and the EU Speakers Conference.

\section{A. Spontaneous Concerted Action of NPs}

Two examples shed light on this type of parliamentary activism in EU trade policy. The first example is the joint letter that 21 chairpersons of the European Affairs Committees of NPs sent to former Commissioner De Gucht in June 2014. ${ }^{46}$ Drafted by the Dutch Tweede Kamer, the letter was signed within COSAC and channeled via the Barroso Initiative. The main purpose was to request the conclusion of TTIP as a mixed agreement.

The teamed-up parliaments held that certain elements of TTIP-especially in the areas of services, transport and investor protection-fell under national competence and requested to approve TTIP because of the important role national parliaments have in the democratic decision-making process of the EU'. This reveals their role perception as autonomous stakeholders in ensuring the legitimacy of EU external relations.

In its reply, the Commission welcomed the role of NPs in ensuring a 'vigorous and wellfounded debate' on TTIP and agreed to provide the requisite support and information. ${ }^{47}$ It argued, furthermore, that what determines the nature of an international agreement is its contents, and added that this can only be determined at the end of negotiations. Yet given the experiences of EU trade agreements with South Korea, Peru and Colombia-all of which were concluded as mixed-the Commission stated that TTIP was also likely to be a mixed agreement. De Gucht had conveyed the same message some five months before in his speech to the German Bundesrat. ${ }^{48}$ The incumbent Trade Commissioner, Cecilia Malmström, consequently affirmed the likelihood of TTIP's mixity. ${ }^{49}$

The second example is the interparliamentary meeting that the French Assemblée nationale organised in June 2015..$^{50}$ The meeting was jointly organised by the European Affairs Committee and the Committee for Economic Affairs and attended by the French Secretary of State for Foreign Trade, one French MEP, and representatives of no less than 24 national parliamentary chambers. This was an opportunity to exchange views on the risks and benefits related to EU trade agreements.

\section{B. EU Speakers Conference}

The EU Speakers Conference also addressed the theme of parliamentary participation in EU international agreements. At its April 2015 meeting in Rome, Speakers requested that national parliamentarians be granted the same level of access to TTIP documents as MEPs, so that they can 'make their orientations known during the negotiations' and not only post facto. They underscored that it was of 'utmost importance for national parliaments to play a definite role in discussing and ratifying' the TTIP, CETA and TISA agreements. ${ }^{51}$ Similar requests were repeated at the Luxembourg Speakers Conference in May 2016. ${ }^{52}$

These joint statements have a declaratory, non-binding character. Yet they add authority to the informal diplomatic effort of NPs to induce the Commission to regard TTIP as a mixed agreement. While no legal obligation exists, political pressure, backed by concerns expressed by elected representatives, is felt at the EU level because disregarding the voices of the Member States'

\footnotetext{
46 Tweede Kamer, 'Letter in the Framework of the Political Dialogue: The Role of National Parliaments in Free Trade Agreements', 25.6.2014.

${ }^{47}$ Letter C(2014) 7557, 16.10.2014.

${ }^{48}$ Karel de Gucht, 'The Transatlantic Trade and Investment Partnership: The Real Debate', 22.5.2014, press release SPEECH/14/406, 5.

${ }^{49}$ EurActiv, 'Malmström: We Can Finish TTIP during the Obama Administration', 28.7.2015, http://eurac.tv/j1g.

${ }^{50} A N$, Compte rendu 217, 17.6.2015, www.assemblee-nationale.fr/14/europe/c-rendus/c0217.asp.

${ }^{51}$ Presidency Conclusions, Speakers Conference, Rome, 20-21.4.2015, points 4-5.

${ }^{52}$ Presidency Conclusions, Speakers Conference, Luxembourg, 22-24.5.2016, point 27.
} 
electorates may erode and or even defeat TTIP..$^{53}$

\section{Conclusion}

This article demonstrates that the key factors of NPs' influence over the executive in EU external trade relations are the nature of the agreement, information access, and the level of fusion between the government and parliamentary majority. The first factor is crucial because the designation of TTIP as a mixed agreement gives NPs the right to veto it and to condition their consent with the attainment of certain goals. The second factor enables them to conduct informed, timely and continuous scrutiny. The third factor confirms that a significant degree of unity between the government, parliamentary majority and the major opposition parties reduces legislative leverage in trade policy. In this regard, non-parliamentary systems are more conducive to stronger parliamentary positioning towards the executive.

TTIP negotiations further highlight the severity of the problem of secrecy in trade negotiations and the intensity of the parliamentary struggle against it. The latter has proven fruitful, however. Pressure by the EP and NPs prompted the Juncker Commission's 'transparency initiative', whereby the Commission's negotiating mandate and TTIP negotiating texts and position papers were published. ${ }^{54}$ This mitigates the information asymmetry between legislatures and executives.

This study also shows that EU international agreements wed international law with EU law dimensions of the legislative-executive relationship. Channels of influence are no longer restricted to the national government but extend to direct liaison with the Commission, the EP and other NPs. As a corollary, the inherently ex post involvement in ratification processes is combined with a more anticipatory ex ante scrutiny, both individually and collectively. This increases the opportunity for parliaments to assert their standpoints, which resembles the instruction-giving component of the US TPA.

However, the government's policy remains central to parliamentary control, the effectiveness of which is highly contingent on domestic law and politics. Yet parliaments' heterogeneity and the Commission's resigned approach relativise NPs' capacity for collective advocacy in EU trade relations. Even so, NPs have displayed considerable aptness in exercising democratic control at both national and EU levels within their constitutional boundaries. This is particularly the province of leftwing parties in the circumstances of divided government.

The sheer magnitude of TTIP is likely to accentuate these dynamics more than any previous EU trade agreement. Close parliamentary surveillance over the TTIP process at both national and EU levels is necessary to redress the democratic shortcomings of EU foreign policy making (Zanon 2010: 38) and this explains why some NPs have requested to be involved in the work of the TLD.

Yet while NPs' concrete influence on the CCP and TTIP negotiations remains difficult to gauge, their scrutiny contributes to the politicisation of transatlantic relations and the creation of a European public sphere that may produce transnational effects. The lack of certainty over the NPs' final say on TTIP has strengthened their communicative function.

Finally, while European integration has multiplied the number of actors and interests involved in foreign affairs, and thus diluted the potential for NPs' influence, it has also given rise to new opportunities for their pronouncement. Due to the dispersal of the sources of power and channels of influence, the executives' foreign policy 'privilege' is slowly transforming to the benefit of NPs insofar as the government is no longer their only interlocutor. The cases of TTIP and EU trade policy vividly illustrate this evolution.

\footnotetext{
${ }^{53}$ Personal correspondence with Commissioner Malmström, Gothenburg, 15 March 2016.

${ }^{54}$ See: http://trade.ec.europa.eu/doclib/press/index.cfm?id=1230 and http://data.consilium.europa.eu/doc/document/ST11103-2013-DCL-1/en/pdf.
} 


\section{References}

Alemanno, Alberto (2015). 'The Regulatory Cooperation Chapter of the Transatlantic Trade and Investment Partnership: Institutional Structures and Democratic Consequences', Journal of International Economic Law, 18:3, 625-640.

Baldwin, Matthew (2006). 'EU Trade Politics—Heaven or Hell?', Journal of European Public Policy, 13:6, 926942.

Bièvre, Dirk de and Andreas Dür (2005). 'Constituency Interests and Delegation in European and American Trade Policy', Comparative Political Studies, 38:10, 1271-1296.

Bronckers, Marco (2013). 'Is Investor-State Dispute Settlement (ISDS) Superior to Litigation Before Domestic Courts? An EU View on Bilateral Trade Agreements', Journal of International Economic Law, 18:3, 655677.

Bungenberg, Marc (2010). 'Going Global? The EU Common Commercial Policy After Lisbon', European Yearbook of International Economic Law, 123-151.

Buonanno, Laurie, Natalia Cuglesan, and Keith Henderson, eds. (2015) The New and Changing Transatlanticism: Politics and Policy Perspectives. Abingdon: Routledge.

Burghardt, Günter (2015). 'The EU/US Transatlantic Relationship: The Indispensable Partnership', Special Issue 'Trade Policy between Law, Diplomacy and Scholarship', European Yearbook of International Economic Law, 2015: 193-226.

Capling, Ann and Patrick Low (2010). 'The Domestic Politics of Trade Policy-Making: State and Non-State Actor Interactions and Forum Choice', in Ann Capling and Patrick Low (eds.), Governments, Non-State Actors and Trade Policy-Making: Negotiating Preferentially or Multilaterally. Cambridge: Cambridge University Press, 4-28.

Carter, Ralph G. and James M. Scott (2009). Choosing to Lead: Understanding Congressional Foreign Policy Entrepreneurs. Durham: Duke University Press.

Conceição-Heldt, Eugénia da (2013). 'Do Agents "Run Amok”? A Comparison of Agency Slack in the EU and US Trade Policy in the Doha Round', Journal of Comparative Policy Analysis: Research and Practice, 15:1, 21-36.

Dashwood, Alan (2010). 'Mixity in the Era of the Treaty of Lisbon', in Christophe Hillion and Panos Koutrakos (eds.), Mixed Agreements Revisited: The EU and Its Member States in the World. Oxford: Hart Publishing, 351-366.

Dimopoulos, Angelos (2010). 'The Effects of the Lisbon Treaty on the Principles and Objectives of the Common Commercial Policy', European Foreign Affairs Review, 15:2, 153-170.

Dür, Andreas and Manfred Elsig (2011). 'Principals, Agents, and the European Union's Foreign Economic Policies', Journal of European Public Policy, 18:3, 323-338.

Eeckhout, Piet (2011). EU External Relations Law. Oxford: Oxford University Press.

Elgström, Ole and Magdalena F. Larsén (2010). 'Free to Trade? Commission Autonomy in the Economic Partnership Agreement Negotiations', Journal of European Public Policy, 17:2, 205-223.

Fabry, Elvire (2015). 'France: A Hotbed of Opposition to the TTIP?', Notre Europe Policy Paper no. 136.

Fahey, Elaine (2013). 'Law and Governance as Checks and Balances in Transatlantic Security: Rights, Redress and Remedies in EU-US Passenger Name Records and the Terrorist Finance Tracking Program', Yearbook of European Law, 32, 368-388.

Fergusson, Ian F. (2015). 'Trade Promotion Authority (TPA) and the Role of Congress in Trade Policy', CRS Report no. RL33743.

Gardner, Anthony L. (2015). 'Guest Editorial-A Vital Partnership: US-EU Relations Are Increasingly Significant in Global Affairs', European Foreign Affairs Review, 20:3, 311-314.

Gattermann, Katjana, Anna-Lena Högenauer and Ariella Huff (2013). 'National Parliaments After Lisbon: Towards Mainstreaming of EU Affairs?', OPAL Online Paper No. 13/2013.

Gstohl, Sieglinde and Dominik Hanf (2014). 'The EU's Post-Lisbon Free Trade Agreements: Commercial Interests in a Changing Constitutional Context', European Law Journal, 20:6, 733-748. 
Hiscox, Michael J. (2002). 'Commerce, Coalitions, and Factor Mobility: Evidence from Congressional Votes on Trade Legislation', American Political Science Review, 96:3, 593-608.

Jančić, Davor (2015). 'Transatlantic Regulatory Interdependence, Law and Governance: The Evolving Roles of the EU and US Legislatures', Cambridge Yearbook of European Legal Studies, 17, 334-359.

Jančić, Davor (2016). 'The Role of the European Parliament and the US Congress in Shaping Transatlantic Relations: TTIP, NSA Surveillance and CIA Renditions', Journal of Common Market Studies, 54:4, 896-912.

Krajewski, Markus (2005). 'External Trade Law and the Constitution Treaty: Towards a Federal and More Democratic Common Commercial Policy?', Common Market Law Review, 42:1, 91-127.

Krajewski, Markus (2013). 'New Functions and New Powers for the European Parliament: Assessing the Changes of the Common Commercial Policy from the Perspective of Democratic Legitimacy', European Yearbook of International Economic Law, 67-85.

Lester, Simon and Inu Barbee (2013). 'The Challenge of Cooperation: Regulatory Trade Barriers in the Transatlantic Trade and Investment Partnership', Journal of International Economic Law, 16:4, 847-867.

Lohmann, Susanne and Sharyn O'Halloran (1994). 'Divided Government and U.S. Trade Policy: Theory and Evidence', International Organization, 48:4, 595-632.

Mansfield, Edward D. and Helen V. Milner (2012). Votes, Vetoes, and the Political Economy of International Trade Agreements. Princeton: Princeton University Press.

Maresceau, Marc (2010). 'A Typology of Bilateral Mixed Agreements', in Christophe Hillion and Panos Koutrakos (eds.), Mixed Agreements Revisited: The EU and Its Member States in the World. Oxford: Hart Publishing, 11-29.

Meunier, Sophie (2005). Trading Voices: The European Union in International Commercial Negotiations. Princeton: Princeton University Press.

Meunier, Sophie and Kalypso Nicolaidis (2006). 'The European Union as a Conflicted Trade Power', Journal of European Public Policy, 13:6, 906-925.

Meuwese, Anne (2015). 'Constitutional Aspects of Regulatory Coherence in TTIP: An EU Perspective', Law and Contemporary Problems, 78:4, 153-174.

Milner, Helen V. and Dustin H. Tingley (2011), 'Who Supports Global Economic Engagement? The Sources of Preferences in American Foreign Economic Policy', International Organization, 65:1, 37-68.

Milner, Helen V. and Benjamin Judkins (2004), 'Partisanship, Trade Policy, and Globalization: Is There a Left-Right Divide on Trade Policy?', International Studies Quarterly, 48:1, 95-119.

Passos, Ricardo (2010). 'Mixed Agreements from the Perspective of the European Parliament', in Christophe Hillion and Panos Koutrakos (eds.), Mixed Agreements Revisited: The EU and Its Member States in the World. Oxford: Hart Publishing, 269-294.

Petersmann, Ernst-Ulrich (2015). 'Transformative Transatlantic Free Trade Agreements without Rights and Remedies of Citizens?', Journal of International Economic Law, 18:3, 2015: 579-607.

Pollack, Mark and Gregory Shaffer, eds. (2001). Transatlantic Governance in the Global Economy. Lanham: Rowman \& Littlefield.

Raunio, Tapio (2014). 'Legislatures and Foreign Policy', in Shane Martin, Thomas Saalfeld and Kaare W. Strøm (eds.), The Oxford Handbook of Legislative Studies. Oxford: Oxford University Press, 549-550.

Sbragia, Alberta (2010). 'The EU, the US, and Trade Policy: Competitive Interdependence in the Management of Globalization', Journal of European Public Policy, 17:3, 368-382.

Schütze, Robert (2014). Foreign Affairs and the EU Constitution: Selected Essays. Cambridge: Cambridge University Press.

Servent, Ariadna R. (2014). 'The Role of the European Parliament in International Negotiations after Lisbon', Journal of European Public Policy, 21:4, 568-586.

Streinz, Rudolf (2015). 'Disputes on TTIP: Does the Agreement Need the Consent of the German Parliament?', Special Issue 'Trade Policy between Law, Diplomacy and Scholarship', European Yearbook of International Economic Law, 271-295.

Telò, Mario (2015). 'Transatlantic Partnership and Global Governance from the EU's Perspective', in JeanFrédéric Morin, Tereza Novotná, Frederik Ponjaert and Mario Telò (eds.), The Politics of Transatlantic Trade Negotiations: TTIP in a Globalized World. Farnham: Ashgate, 27-44.

Vogel, David and Johan Swinnen, eds. (2011). Transatlantic Regulatory Cooperation. The Shifting Roles of the $E U$, the US and California. Cheltenham: Edward Elgar. 
Woolcock, Stephen (2012). European Union Economic Diplomacy: The Role of the EU in External Economic Relations. Farnham: Ashgate.

Woolcock, Stephen (2014). 'EU Policy on Preferential Trade Agreements in the 2000s: A Reorientation towards Commercial Aims', European Law Journal, 20:6, 718-732.

Young, Alasdair R. and John Peterson (2006). 'The EU and the New Trade Politics', Journal of European Public Policy, 13:6, 795-814.

Zanon, Flavia (2010). 'EU Foreign Policy Cooperation: A Challenge for National Parliaments?', European Foreign Affairs Review, 15:1, 19-38. 